\title{
PEMANFAATAN KULIT DAGING BUAH KOPI FERMENTASI DENGAN MIKROORGANISME LOKAL DALAM PAKAN TERHADAP KONDISI DAN PERKIRAAN BOBOT KERBAU MURRAH JANTAN (Bubalus bubalis)
}

\author{
(Utilization of Fermented Pod Coffee by Local Microorganisms in Feed on Body \\ Condition and Weight Estimate of Murrah Buffalo Bulls)
}

\author{
Enos Sembiring ${ }^{1}$, Iskandar Sembiring ${ }^{2}$ dan Hasnudi ${ }^{2}$ \\ 1. Mahasiswa Program Studi Peternakan Fakultas Pertanian Universitas Sumatera Utara \\ 2. Staf Pengajar Program Studi Peternakan Fakultas Pertanian Universitas Sumatera Utara
}

\begin{abstract}
Fermented pod coffee with local microorganisms can increasing the protein of feed on the implications of improved feed quality. This study aimed to determine the effects of fermented pod coffee with local microorganisms in feed to condition and estimate weight of murrah buffalo bulls (Bubalus bubalis). The research was conducted at the Balai Pembibitan Ternak Unggul Babi dan Kerbau in Silangit village, Siborongborong Subdistrict at North Tapanuli District, North Sumatra Province on April-September 2012. This research used Latin square design (RBSL) were consist of 4 treatments. The treatments were P0 $(20 \%$ unfermented pod coffee), P1 (10\% fermented pod coffee), P2 (20\% fermented pod coffee) and P3 (30\% fermented pod coffee).The results showed that the usage of various level fermented pod coffee with local microorganisms gived significantly different effect $(P<0.05)$ on feed intake, body condition based on bony ribs and hip bones. Chest circumference and body length were significantly $(P<0.01)$ to the weight estimate of Murrah buffaloes. It can be concluded that fermented pod coffee can be used as feed of Murrah buffalo.
\end{abstract}

Keywords : Fermented pod coffee, local microorganisms, body condition, Weights estimated, Murrah buffalo

\begin{abstract}
ABSTRAK
Kulit daging buah kopi fermentasi dengan mikroorganisme lokal dapat meningkatkan kandungan protein pakan yang berimplikasi pada peningkatan kualitas pakan. Penelitian ini bertujuan untuk mengetahui pengaruh pemberian kulit daging buah kopi yang difermentasi dengan Mikroorganisme lokal dalam pakan terhadap kondisi dan perkiraan bobot kerbau murrah jantan (Bubalus bubalis). Penelitian dilaksanakan di Balai Pembibitan Ternak Unggul Babi dan Kerbau di desa Silangit Kecamatan Siborong-borong Kabupaten Tapanuli Utara, Sumatera Utara pada bulan April - September 2012. Rancangan penelitian yang digunakan adalah bujur sangkar latin (RBSL) yang terdiri dari 4 perlakuan. Perlakuan terdiri atas $\mathrm{P}_{0}(20 \%$ kulit kopi tanpa fermentasi); $\mathrm{P}_{1}\left(10 \%\right.$ kulit kopi fermentasi); $\mathrm{P}_{2}\left(20 \%\right.$ kulit kopi fermentasi) dan $\mathrm{P}_{3}$ (30\% kulit kopi fermentasi).Hasil penelitian menunjukkan bahwa penggunaan berbagai level kulit kopi fermentasi dengan mikroorganisme lokal berbeda nyata $(\mathrm{P}<0,05)$ terhadap konsumsi pakan, kondisi tubuh berdasarkan tonjolan tulang rusuk dan tonjolan tulang pinggul. Lingkar dada dan panjang tubuh sangat signifikan $(\mathrm{P}<0,01)$ terhadap perkiraan bobot kerbau murrah. Dapat disimpulkan bahwa kulit daging buah kopi yang telah difermentasi dapat digunakan sebagai pakan kerbau murrah.
\end{abstract}

Kata Kunci: Kulit daging buah kopi fermentasi, mikroorganisme lokal, kondisi tubuh, perkiraan bobot, kerbau murrah. 


\section{PENDAHULUAN}

Ternak kerbau berfungsi multiguna yaitu sebagai penghasil daging, susu dan kerja. Kerbau merupakan salah satu ternak ruminansia besar yang memiliki keunggulan tersendiri untuk dikembangkan di Indonesia. Beberapa keunggulan dari ternak kerbau adalah dapat bertahan hidup dengan pakan berkualitas rendah, mampu hidup dikawasan yang relatif sulit, kemampuan mencerna hijauan lebih baik daripada sapi. Hal tersebut disebabkan secara keseluruhan baik mikroba maupun cairan rumen kerbau lebih mampu mencerna berbagai pakan dengan kandungan serat kasar tinggi (Reksohadiprojo, 1984).

Kerbau Murrah adalah salah satu bangsa kerbau yang diternakkan di Indonesia, khususnya di daerah sekitar Medan Sumatera Utara oleh para pekerja perkebunan dan bekas pekerja perkebunan yang didatangkan dari India selama masa penjajahan Belanda. Bentuk tubuh kerbau Murrah padat massive, kuat dengan pungung pendek dan luas. Ekor mempunyai bulu kipas berwarna putih, tanduk melingkar dalam bentuk spiral serta warna tubuh pada umumnya hitam.

Salah satu faktor yang mempengaruhi keberhasilan dalam pengelolaan ternak adalah faktor pakan, pakan ini berasal dari hijauan yang jumlahnya terbatas pada saat-saat tertentu, serta hasil samping pertanian dan perkebunan. Untuk menanggulangi keterbatasan tersebut dilakukanlah metode pengawetan dan fermentasi. Kulit kopi merupakan salah satu alternatif untuk mengatasi masalah pakan. Menurut data Deptan (2011), produksi kopi nasional mencapai sekitar 687 ribu ton per tahun, dengan jenis yang umum dijumpai adalah arabika dan robusta. $40-45 \%$ dari buah kopi adalah kulit daging buah yang berpotensi sebagai pakan alternatif ternak. Kadar air kulit daging buah kopi cukup tinggi (53\%) menyebabkan produk ini mudah rusak dan apabila diberikan dalam bentuk segar kurang disukai ternak. Teknologi fermentasi dapat mengatasi kendala tersebut, sehingga meningkatkan manfaatnya sebagai pakan ternak.

Kurangnya minat peternak memilih kerbau sebagai ternak peliharaannya disebabkan oleh kurangnya informasi mengenai ternak kerbau sehingga peternak tidak begitu tahu potensi yang dimiliki ternak kerbau. Kurangnya minat peternak memilih kerbau sebagai ternak peliharaannya disebabkan oleh kurangnya informasi mengenai ternak kerbau sehingga peternak tidak begitu tahu potensi yang dimiliki ternak kerbau. Kerbau biasanya dipelihara dalam jumlah yang kecil oleh peternak kecil atau peternak miskin didaerah-daerah tertentu (Williamson, 1993). 
Jumlah populasi kerbau murrah yang relatif kecil membuat proses penimbangan dengan alat timbang menjadi tidak efektif karena peternak harus mengeluarkan biaya lebih untuk menyediakan timbangan dikandang. Cara lain yang dapat dilakukan peternak untuk mengetahui berat badan kerbau adalah dengan menggunakan metode pengukuran. Cara ini cukup efektif dan biayanya relatif lebih murah.

\section{BAHAN DAN METODE PENELITIAN}

\section{Lokasi dan Waktu Penelitian}

Penelitian dilaksanakan di Balai Pembibitan Ternak Unggul Babi dan Kerbau di desa Silangit Kecamatan Siborong-borong Kabupaten Tapanuli Utara, Sumatera Utara. Penelitian ini dilaksanakan selama 4 bulan dimulai bulan April sampai dengan Agustus 2012.

\section{Bahan dan Alat Penelitian}

Bahan yang digunakan dalam penelitian adalah 4 ekor ternak Kerbau Murrah jantan berumur 1 tahun hingga 1 tahun 3 bulan sebagai objek yang akan diteliti, hijauan, konsentrat yang terdiri dari kulit daging buah kopi, onggok, dedak padi, bungkil inti sawit, tongkol jagung, molases, urea, garam, mineral mix dan kapur sebagai bahan pakan. Air tebu, ragi tempe, ragi tape dan youghurt sebagai bahan fermentator pembuatan inokulan cair serta obatobatan seperti obat cacing wormzol, vitamin B-Kompleks dan air minum.

Alat yang digunakan kandang individu 4 unit beserta perlengkapannya. Tempat pakan sebagai wadah pakan. Ember 8 buah sebagai wadah/tempat air minum dan konsentrat. Lesung sebagai alat untuk menggiling kulit kopi. Timbangan kapasitas $500 \mathrm{~kg}$ sebagai alat penimbang bobot badan sapi. Timbangan dengan kapasitas $10 \mathrm{~kg}$ sebagai alat penimbang bahan pakan. Terpal sebagai tempat fermentasi kulit kopi. alat kebersihan, alat tulis, kalkulator dan alat penerangan. Termometer sebagai alat untuk mengukur suhu. Kandungan nutrisi bahan pakan tersaji pada Tabel 1 dan 2 .

\section{Pembuatan Inokulan Cair}

Dimasukkan air sumur sebanyak 10 liter ke dalam galon lalu dimasukkan air tebu sebanyak 1,5 liter lalu dimasukkan ragi tape dan ragi tempe masing-masing 60 gr serta youghurt 2 sendok makan kemudian diaduk bahan sampai merata lalu ditutup dengan plastik dan dibiarkan selama tiga hari, apabila plastik penutup galon telah kembung berarti mikroba didalam galon telah aktif dan inokulan cair siap untuk digunakan. 


\section{Pembuatan Kulit Daging Buah Kopi Fermentasi}

Kulit daging buah kopi dicampur dengan dedak padi sebanyak 15\% dari berat kulit daging buah kopi, campuran kulit daging buah kopi dengan padi disiram dengan inokulan cair secara merata dengan perbandingan antara inokulan cair dan kulit daging buah kopi adalah 1 liter : $25 \mathrm{~kg}$. Kulit daging buah kopi ditutup dengan selimut sabut kelapa lalu dibolak balik dan diukur suhunya setiap hari, setelah 5 hari kulit daging buah kopi fermentasi di bongkar dan di angin-anginkan lalu digrinder siap digunakan sebagai bahan pakan.

Tabel 1. Kandungan nutrisi bahan pakan

\begin{tabular}{|c|c|c|c|c|c|}
\hline \multirow[b]{2}{*}{ Bahan Pakan } & \multicolumn{5}{|c|}{ Kandungan (\%) } \\
\hline & $\begin{array}{l}\text { Bahan } \\
\text { Kering }\end{array}$ & $\begin{array}{c}\text { Protein } \\
\text { Kasar }\end{array}$ & $\begin{array}{c}\text { Serat } \\
\text { Kasar }\end{array}$ & $\begin{array}{l}\text { Lemak } \\
\text { Kasar }\end{array}$ & TDN \\
\hline $\begin{array}{l}\text { Kulit daging buah kopi tanpa } \\
\text { fermentasi }\end{array}$ & $56,79^{\mathrm{a}}$ & $11,90^{\mathrm{a}}$ & $30,40^{\mathrm{a}}$ & $4,25^{\mathrm{a}}$ & $50,67^{\mathrm{a}}$ \\
\hline Kulit daging buah kopi fermentasi & $93,84^{\mathrm{a}}$ & $15,61^{\mathrm{a}}$ & $23,67^{\mathrm{a}}$ & $2,34^{\mathrm{a}}$ & $59,23^{\mathrm{a}}$ \\
\hline Onggok & $90,17^{\mathrm{b}}$ & $3,93^{\mathrm{b}}$ & $10,92^{\mathrm{b}}$ & $0,68^{\mathrm{b}}$ & $77,89^{\mathrm{b}}$ \\
\hline Dedak padi & $89,10^{\mathrm{d}}$ & $13,80^{\mathrm{d}}$ & $11,54^{\mathrm{d}}$ & $7,80^{\mathrm{d}}$ & $64,99^{\mathrm{d}}$ \\
\hline Bungkil inti sawit & $91,11^{\mathrm{d}}$ & $15,89^{\mathrm{d}}$ & $17,35^{\mathrm{d}}$ & $7,59^{\mathrm{d}}$ & $81,00^{\mathrm{d}}$ \\
\hline Tongkol jagung & $66,13^{\mathrm{c}}$ & $3,99^{\mathrm{c}}$ & $28,89^{\mathrm{c}}$ & $1,58^{\mathrm{c}}$ & $56,89^{\mathrm{c}}$ \\
\hline Molases & $67,50^{\mathrm{d}}$ & $3,40^{\mathrm{d}}$ & $0,38^{\mathrm{d}}$ & $0,08^{\mathrm{d}}$ & $57,93^{\mathrm{d}}$ \\
\hline Sumber: $\begin{aligned} \mathrm{a} & =\text { Laboratorium Nutrisi } \\
\mathrm{b} & =\text { Moertinah }(1984) \\
\mathrm{c} & =\text { Hartadi, } \text { et al. },(1986) . \\
& \mathrm{d}=\text { Laboratorium Ilmu M }\end{aligned}$ & a Penelitiar & & 2011) & & \\
\hline
\end{tabular}

Tabel 2. Komposisi susunan ransum

\begin{tabular}{lcccc}
\hline & \multicolumn{5}{c}{ Jumlah Bahan Pakan } \\
\cline { 2 - 5 } Bahan Pakan & P0 & P1 & P2 & P3 \\
\hline Kulit Kopi Fermentasi & 0 & 10 & 20 & 30 \\
Kulit Kopi Tanpa Fermentasi & 20 & 0 & 0 & 0 \\
Onggok & 13 & 13 & 13 & 15,6 \\
Dedak & 15 & 15 & 14 & 12,5 \\
BIS & 34 & 34 & 30,5 & 24,5 \\
Tongkol Jagung & 6 & 16 & 10,5 & 5,4 \\
Molases & 7 & 7 & 7 & 7 \\
Urea & 2 & 2 & 2 & 2 \\
Mineral Mix & 1 & 1 & 1 & 1 \\
Garam & 1 & 1 & 1 & 1 \\
Kapur & 1 & 1 & 1 & 1 \\
\hline Total & 100 & 100 & 100 & 100 \\
\hline Nutrisi & \multicolumn{5}{c}{} \\
Protein Kasar & 16,44 & 16,02 & 16,67 & 16,97 \\
Lemak Kasar & 4,79 & 4,33 & 4,13 & 3,73 \\
Serat Kasar & 16,89 & 16,07 & 16,12 & 16,08 \\
TDN & 65,02 & 66,49 & 65,80 & 65,02 \\
\hline
\end{tabular}




\section{Metode Penelitian}

Adapun rancangan penelitian yang digunakan adalah rancangan bujur sangkar latin (RBSL) dengan 4 perlakuan. Perlakuan yang akan diteliti sebagai berikut :

$\mathrm{P} 0=$ Hijauan + konsentrat dengan kulit daging buah kopi tanpa fermentasi $20 \%$

$\mathrm{P} 1=$ Hijauan + konsentrat dengan kulit daging buah kopi fermentasi $10 \%$

$\mathrm{P} 2=$ Hijauan + konsentrat dengan kulit daging buah kopi fermentasi $20 \%$

P3 = Hijauan + konsentrat dengan kulit daging buah kopi fermentasi $30 \%$

Menurut Sastrosupadi (2000), metode linier percobaan yang digunakan adalah :

$$
\mathbf{Y}_{\mathrm{ijk}}+\boldsymbol{\mu}+\mathbf{T}_{\mathrm{i}}+\mathbf{B}_{\mathrm{j}}+\mathbf{K}_{\mathrm{k}}+\boldsymbol{€}_{\mathrm{ijk}}
$$

Keterangan :

$\mathrm{Y}_{\mathrm{ijk}}=$ hasil pengamatan dari perlakuan ke-i, baris ke-j dan kolom ke-k

$\mathrm{T}_{\mathrm{i}}=$ pengaruh perlakuan ke-i

$B_{j}=$ pengaruh baris ke- $\mathrm{j}$

$\mathrm{K}_{\mathrm{k}}=$ pengaruh kolom ke-k

$\mu \quad=$ nilai tengah umum

$€_{\mathrm{ijk}}=$ pengaruh galat karena perlakuan ke-i, baris ke-j dan kolom ke-k

Faktor-faktor yang mempengaruhi bobot badan kerbau murrah dapat dilihat dengan menggunakan analisis regresi linear berganda. Menurut Djalal dan Usman (2002) model pendugaan yang digunakan:

$$
\hat{Y}=a+b 1 X 1+b 2 X 2+b 3 X 3+\mu
$$

Keterangan:

$$
\begin{array}{ll}
\hat{\mathrm{Y}} & \begin{array}{l}
\text { : bobot badan }(\mathrm{Y}: \text { topi) yang dipengaruhi beberapa faktor } \\
\text { dalam menduga bobot badan kerbau Murrah }
\end{array} \\
\mathrm{a} & : \text { koefisien intercept (konstanta) } \\
\mathrm{b} 1 \mathrm{~b} 2 \mathrm{~b} 3 & : \text { koefisien regresi } \\
\mathrm{X} 1 & \text { : lingkar dada }(\mathrm{cm}) \\
\mathrm{X} 2 & \text { : panjang tubuh }(\mathrm{cm}) \\
\mu & \text { : variabel lain yang tidak diteliti }
\end{array}
$$

\section{Parameter Penelitian}

1. Konsumsi Pakan (Bahan Kering)

Konsumsi Pakan dihitung berdasarkan jumlah pakan yang diberikan dikurangi dengan sisa pakan dan pakan terbuang selama 4 bulan penelitian. 
2. Penilaian Kondisi Tubuh

Tonjolan tulang rusuk dan tulang pinggul

Tonjolan tulang rusuk diukur melalui pengamatan terhadap tampilan kondisi tubuh ternak kerbau. Tonjolan tulang pinggul diukur menggunakan penggaris atau pita ukur.

3. Perkiraan Bobot Badan

Lingkar dada

Lingkar dada diukur mengikuti lingkaran dada / tubuh tepat di belakang bahu melewati gumba dengan menggunakan pita ukur.

Panjang tubuh

Panjang tubuh diukur dengan cara menarik garis horisontal dari tepi depan sendi bahu sampai tepi tulang duduk dengan menggunakan pita ukur.

\section{HASIL DAN PEMBAHASAN}

\section{Rekapitulasi Hasil Penelitian}

Rekapitulasi hasil penelitian dari penggunaaan berbagai level kulit kopi yang difermentasi dengan mikro organisme lokal dalam konsentrat terhadap penilaian kondisi dan perkiraan berat kerbau murrah dapat dilihat pada Tabel 3.

Tabel 3. Rekapitulasi Hasil Penelitian

\begin{tabular}{cccc}
\hline \multirow{2}{*}{ Perlakuan } & \multicolumn{3}{c}{ Parameter } \\
\cline { 2 - 4 } & $\begin{array}{c}\text { Konsumsi Pakan } \\
(\text { kg/ekor/hari) }\end{array}$ & $\begin{array}{c}\text { Penilaian Kondisi Tubuh } \\
\text { Tonjolan Tulang Rusuk }\end{array}$ & Tonjolan tulang Pinggul \\
\hline P0 & $6,51^{\mathrm{a}}$ & $3,06^{\mathrm{a}}$ & $3,00^{\mathrm{a}}$ \\
P1 & $7,06^{\mathrm{b}}$ & $3,50^{\mathrm{b}}$ & $3,44^{\mathrm{b}}$ \\
P2 & $6,93^{\mathrm{ab}}$ & $3,44^{\mathrm{b}}$ & $3,31^{\mathrm{ab}}$ \\
P3 & $6,87^{\mathrm{ab}}$ & $3,38^{\mathrm{ab}}$ & $3,25^{\mathrm{ab}}$ \\
\hline
\end{tabular}

Keterangan : Superskrip yang berbeda pada baris yang sama menunjukkan perbedaan yang nyata $(\mathrm{P}<0,05)$ 


\section{Konsumsi Pakan (Bahan Kering)}

Konsumsi pakan adalah kemampuan ternak dalam menghabiskan sejumlah pakan yang diberikan. Konsumsi pakan dapat dihitung dengan pengurangan jumlah pakan yang diberikan dengan sisa pakan yang ada. Berdasarkan Tabel 3 dapat dilihat rataan konsumsi pakan tertinggi terdapat pada perlakuan P1 (pakan dengan kulit kopi fermentasi dengan mikroorganisme lokal sebanyak 10\%) sebesar 7,06 kg/ekor/hari, sedangkan rataan konsumsi pakan terendah terdapat pada perlakuan P0 (pakan dengan kulit kopi tanpa fermentasi sebanyak 20\%) sebesar 6,51 kg/ekor/hari, dengan konsumsi pakan rata-rata adalah 6,84 $\mathrm{kg} / \mathrm{ekor} / \mathrm{hari}$ dalam bahan kering.

Hasil analisis ragam menunjukkan bahwa pemberian 20\% kulit kopi tanpa fermentasi dan berbagai level $(10 \%, 20 \%, 30 \%)$ penggunaan kulit kopi yang difermentasi dengan mikroorganisme lokal dalam konsentrat memberikan pengaruh yang berbeda nyata $(\mathrm{P}<0,05)$ terhadap konsumsi pakan kerbau murrah dalam bahan kering.

Berdasarkan uji Tukey taraf 5\% terlihat bahwa konsumsi pada perlakuan P0 memberikan nilai rataan yang berbeda dengan perlakuan P1, namun memberikan nilai rataan yang tidak berbeda dengan perlakuan P2 dan P3. Pada perlakuan pakan, konsumsi tertinggi terdapat pada perlakuan P1 yaitu sebesar 7,06, namun memberikan nilai rataan yang tidak berbeda terhadap perlakuan P2 dan P3. Namun demikian, semua perlakuan fermentasi yang digunakan menghasilkan rataan yang lebih besar dari perlakuan P0 (Pakan dengan kulit kopi tanpa fermentasi sebanyak 20\%).

Berdasarkan hasil penelitian Ranjhan (1997), kebutuhan nutrisi kerbau murrah per hari dalam bahan kering adalah $5 \mathrm{~kg} / \mathrm{ekor} /$ hari, sedangkan rataan konsumsi pakan selama penelitian sebesar 6,84 kg/ekor/hari dalam bahan kering. Rataan konsumsi pakan selama penelitian lebih tinggi daripada tingkat kebutuhan nutrisi harian kerbau murrah, berarti kebutuhan nutrisi harian kerbau murrah dapat terpenuhi.

Palatabilitas dari pakan yang berbeda serta bobot badan Kerbau Murrah yang tidak seragam inilah memberikan pengaruh terhadap tingkat konsumsi pakan. Sesuai dengan pernyataan Piliang (1997) yang menyatakan bahwa konsumsi ransum dipengaruhi beberapa faktor diantaranya adalah palatabilitas ransum, bentuk fisik ransum, bobot badan, jenis kelamin, temperatur lingkungan. Selanjutnya menurut Church dan Pond (1980) menunjukkan bahwa palatabilitas pakan dipengaruhi oleh faktor fisik dan kimiawi pakan yang akan berpengaruh terhadap fisiologis ternak dalam ransangan penglihatan, penciuman dan rasa dalam mengkonsumsi pakan. 


\section{Penilaian Kondisi Tubuh}

\section{Tonjolan Tulang Rusuk}

Tonjolan tulang rusuk diukur melalui pengamatan terhadap tampilan tulang rusuk yang membayang pada ternak kerbau murrah lalu ditampilkan dalam bentuk skor yang dinotasikan kedalam bentuk angka 1,2,3,4 dan 5. Berdasarkan Tabel 3 rataan skor tertinggi terdapat pada perlakuan P1 (pakan dengan kulit kopi fermentasi dengan MOL sebanyak $10 \%$ ) sebesar 3,50, sedangkan rataan skor terendah terdapat pada perlakuan P0 (Pakan dengan kulit kopi tanpa fermentasi sebanyak 20\%) sebesar 3,06.

Hasil analisis ragam menunjukkan bahwa pemberian 20\% kulit kopi tanpa fermentasi dan berbagai level $(10 \%, 20 \%, 30 \%)$ penggunaan kulit kopi yang difermentasi dengan mikro organisme lokal dalam konsentrat memberikan pengaruh yang berbeda nyata $(\mathrm{P}<0,05)$ terhadap penilaian kondisi tubuh berdasarkan tonjolan tulang rusuk.

Berdasarkan uji Tukey taraf 5\% terlihat bahwa penilaian kondisi tubuh kerbau murrah berdasarkan tonjolan tulang rusuk pada perlakuan P0 memberikan nilai rataan yang berbeda dengan perlakuan $\mathrm{P} 1$ dan $\mathrm{P} 2$, namun memberikan nilai rataan yang tidak berbeda dengan perlakuan P3. Pada perlakuan fermentasi penilaian kondisi tubuh kerbau murrah berdasarkan tonjolan tulang rusuk tertinggi terdapat pada perlakuan P1 yaitu sebesar 3,50, namun memberikan nilai rataan yang tidak berbeda terhadap perlakuan P2 dan P3. Namun demikian, semua perlakuan fermentasi yang digunakan menghasilkan rataan yang lebih besar dari perlakuan P0 (Pakan dengan kulit kopi tanpa fermentasi sebanyak 20\%).

Kisaran skor pada penilaian kondisi tubuh berdasarkan tonjolan tulang rusuk kerbau murrah adalah 3,06-3,50. Hal ini menunjukan bahwa kerbau murrah tersebut mempunyai kondisi tubuh yang relatif sedang. Sesuai dengan pernyataan Rutter, et al., (2000), tubuh ternak dapat dikategorikan dalam skor 3 dan dianggap berukuran sedang apabila hanya sebagian dari tulang rusuk (kurang dari 8 buah) tampak membayang dibalik kulit dan dapat dirasakan oleh tekanan tangan.

\section{Tonjolan Tulang Pinggul}

Tonjolan tulang pinggul diukur melalui pengukuran terhadap tulang pinggul yang menonjol pada ternak kerbau murrah lalu ditampilkan dalam bentuk skor yang dinotasikan kedalam bentuk angka 1,2,3,4 dan 5. Berdasarkan Tabel 3 rataan skor tertinggi terdapat pada perlakuan P1 (Pakan dengan kulit kopi fermentasi dengan MOL sebanyak 10\%) sebesar 3,44, 
sedangkan rataan skor terendah terdapat pada perlakuan P0 (Pakan dengan kulit kopi tanpa fermentasi sebanyak 20\%) sebesar 3,00.

Hasil analis ragam menunjukkan bahwa pemberian 20\% kulit kopi tanpa fermentasi dan berbagai level $(10 \%, 20 \%, 30 \%)$ penggunaan kulit kopi yang difermentasi dengan mikro organisme lokal dalam konsentrat memberikan pengaruh yang berbeda nyata $(\mathrm{P}<0,05)$ terhadap penilaian kondisi tubuh berdasarkan tonjolan tulang pinggul.

Berdasarkan uji Tukey taraf 5\% terlihat bahwa penilaian kondisi tubuh kerbau murrah berdasarkan tonjolan tulang pinggul pada perlakuan P0 memberikan nilai rataan yang berbeda dengan perlakuan P1, namun memberikan nilai rataan yang tidak berbeda dengan perlakuan P2 dan P3. Pada perlakuan fermentasi penilaian kondisi tubuh kerbau murrah berdasarkan tonjolan tulang pinggul tertinggi terdapat pada perlakuan P1 yaitu sebesar 3,44, dan memberikan nilai rataan yang tidak berbeda terhadap perlakuan P2 dan P3. Namun demikian, semua perlakuan fermentasi yang digunakan menghasilkan rataan yang lebih besar dari perlakuan P0 (Pakan dengan kulit kopi tanpa fermentasi sebanyak 20\%).

Kisaran skor pada penilaian kondisi tubuh berdasarkan tonjolan tulang pinggul kerbau murrah adalah 3,00-3,44. Hal ini menunjukan bahwa kerbau murrah tersebut mempunyai kondisi tubuh yang relatif sedang. Sesuai dengan pernyataan Rutter, et al., (2000), tubuh ternak dapat dikategorikan dalam skor 3 dan dianggap berukuran sedang apabila pangkal ekor dan tulang pinggul mulai tertutupi lemak dan dapat dengan mudah dirasakan tangan.

Hasil penelitian menunjukkan bahwa pemberian 20\% kulit kopi tanpa fermentasi dan berbagai level $(10 \%, 20 \%, 30 \%)$ penggunaan kulit kopi yang difermentasi dengan mikro organisme lokal dalam konsentrat memberikan pengaruh yang berbeda nyata terhadap penilaian kondisi tubuh kerbau murrah berdasarkan tonjolan tulang rusuk dan tonjolan tulang pinggul, hal ini disebabkan oleh hubungan antara tingkat konsumsi dan pertambahan bobot badan yang berbanding lurus.

Thalib et al., (2001) menyatakan bahwa pertambahan bobot badan ternak sangat dipengaruhi oleh kualitas dan kuantitas pakan, maksudnya penilaian pertambahan bobot badan ternak sebanding dengan ransum yang dikonsumsi. Penilaian kondisi tubuh kerbau murrah memiliki kaitan yang sangat erat dengan pertambahan bobot badan, kerbau murrah yang semakin berat akan memperlihatkan kondisi yang semakin gemuk, terlihat dari jumlah tulang rusuk yang membayang dan tonjolan tulang pinggul yang semakin berkurang. Hal 
tersebut sesuai dengan pernyataan Nielsen (2002) bahwa bobot badan memiliki hubungan yang positif terhadap tingkat kegemukan ternak.

\section{Perkiraan Bobot Kerbau Murrah}

Pengujian terhadap faktor-faktor yang mempengaruhi perkiraan bobot kerbau Murrah di Balai Pembibitan Ternak Unggul Babi dan Kerbau di desa Silangit Kecamatan Siborongborong Kabupaten Tapanuli Utara, Sumatera Utara digunakan analisis regresi linier berganda, dimana yang menjadi variabel bebas (independent) adalah lingkar dada $\left(\mathrm{X}_{1}\right)$, dan panjang tubuh $\left(\mathrm{X}_{2}\right)$, sedangkan yang menjadi variabel terikat/tidak bebas (dependent) adalah berat badan (Y).

Berdasarkan hasil yang telah diperoleh, maka untuk melihat faktor-faktor yang mempengaruhi perkiraan bobot kerbau murrah dengan menggunakan analisis regresi linear berganda dapat dilihat pada Tabel 2.

Tabel 4. Rekapitulasi Hasil Penelitian Terhadap Perkiraan Berat Kerbau Murrah

\begin{tabular}{ccc}
\hline Variabel & Signifikan & Keterangan \\
\hline Lingkar Dada $\left(\mathrm{X}_{1}\right)$ & 0,001 & Berpengaruh sangat nyata \\
Panjang Tubuh $\left(\mathrm{X}_{2}\right)$ & 0,001 & Berpengaruh sangat nyata \\
\hline
\end{tabular}

Tabel 2 menunjukkan bahwa nilai Signifikan 0,001 untuk lingkar dada dan panjang tubuh yang berarti lingkar dada dan panjang tubuh memberikan pengaruh yang sangat nyata $(<0,01)$ terhadap bobot badan kerbau murrah. Hal ini sesuai dengan pernyataan Kadarsih (2003) bobot badan ternak merupakan salah satu indikator produktivitas ternak yang dapat diduga berdasarkan linear tubuh ternak meliputi lingkar dada, panjang badan dan tinggi badan. Selain itu tingkat korelasi antara lingkar dada dan panjang tubuh terhadap bobot badan sangat tinggi yaitu mencapai 98\%. Persamaan pendugan bobot badan yang diperoleh dengan menggunakan analisis regresi linier berganda adalah sebagai berikut :

$$
\mathrm{Y}=0,11+1,021 \mathrm{X}_{1}+1,385 \mathrm{X}_{2}
$$

Keterangan : $\mathrm{Y}=$ Berat Badan

$\mathrm{X}_{1}=$ Lingkar Dada

$\mathrm{X}_{2}=$ Panjang Tubuh

Berdasarkan Hasil Regresi di atas dapat diketahui:

1. Nilai Konstanta/Intersept adalah sebesar 0,11. Artinya dalam penggunaan rumus, selain dari hasil penghitungan variabel bebas yaitu lingkar dada dan panjang tubuh, bobot kerbau murrah juga akan ditambah sebesar nilai konstanta yaitu $0,11 \mathrm{~kg}$. 
2. R Square bernilai $98 \%$, artinya bahwa semua variabel bebas lingkar dada dan panjang tubuh mempengaruhi variabel terikat sebesar 98\% dan selebihnya yaitu sebesar 2\% dijelaskan oleh variabel lain $(\mu)$ yang tidak diteliti dalam penelitian ini.

3. Apabila variabel bebas lingkar dada $\left(\mathrm{X}_{1}\right)$ mengalami kenaikan sebesar $1 \mathrm{~cm}$, maka akan terjadi penambahan bobot badan (Y) sebesar 1,021 kg.

4. Apabila variabel bebas panjang tubuh $\left(\mathrm{X}_{2}\right)$ mengalami kenaikan sebesar $1 \mathrm{~cm}$, maka akan terjadi penambahan bobot badan (Y) sebesar 1,385 kg.

\section{KESIMPULAN}

Kulit daging buah kopi yang difermentasi dengan mikroorganisme lokal mampu meningkatkan kondisi dan bobot badan kerbau Murrah. Persamaan yang menggambarkan hubungan antara lingkar dada dan panjang tubuh terhadap bobot badan adalah $\mathrm{Y}=0,110+$ $1,021 \mathrm{X}_{1}+1,385 \mathrm{X}_{2}$. Fungsi rumus tersebut memudahkan peternak untuk mengetahui bobot badan ternak tanpa harus melakukan penimbangan, cara menggunakannya yaitu dengan memasukkan ukuran lingkar dada pada $\mathrm{X}_{1}$ dan ukuran panjang tubuh pada $\mathrm{X}_{2}$.

\section{DAFTAR PUSTAKA}

Church, D. C. and W.G.Pond. 1980. Basic Animal Nutrition and Feeding. $3^{\text {rd }}$ ed Jhon Willey and Sons, New York.

Deptan. 2012. Populasi Kerbau Tahun 2011. Diakses pada http://www.deptan.go.id/news/detail.php.id [07 Februari 2012]. 17.31 wib.

Djalal, N. dan H. Usman. 2002. Penggunaan Teknik Ekonometri. Edisi I. Cetakan I. PT. Raja Grafindo Persada. Jakarta.

Hartadi, H., S. Reksohadiprodjo dan A. D. Tillman. 1986. Tabel Komposisi Pakan untuk Indonesia Cetakan ke -2. Gadjah Mada University Press, Yogyakarta.

Kadarsih, S. 2003. Peranan ukuran tubuh terhadap bobot badan sapi Bali di provinsi Bengkulu. Jurnal penelitian UNIB, IX (1) : 45 - 48.

Laboratorium Ilmu Pakan Ternak, 2005. Hasil Analisis Bahan Pakan. Departemen Peternakan FP USU, Medan.

Laboratorium Nutrisi Loka Penelitian Kambing Potong, 2011. Hasil Analisis Bahan Pakan. Loka Penelitian Kambing Potong. Sei Putih, Galang.

Moertinah, S., 1984. Limbah Tapioka di Indonesia dan Kemungkinan Penangan Dasar Studi Pengelolaan Sumberdaya dan Lingkungan. IPB, Bogor.

Nielsen, K. 2002. Animal Physiology : Adaptation and Environment. Ed Ke-5. Cambridge University Press. Cambridge.

Pilliang, G. W., 1997. Strategi penyediaan Pakan Ternak Berkelanjutan Melalui Pemanfaatan Energi Alternatif. Orasi Ilmiah. Fakultas Peternakan IPB,Bogor.

Ranjhan S.K.. 1997. Animal Nutrition in the Tropics. Fourth revised edition. Vikas Publishing House, New Delhi, India. 
Reksohadiprodjo., S. 1984. Pengantar Ilmu Peternakan Tropik. BPFE. Yogyakarta.

Rutter, S. M., R. A. Champion, and P. D. Penning. 2000. An automatic system to record foraging behaviour in free-ranging ruminants. Appl. Anim. Behav. Sci. 54:185.

Sastrosupadi, A., 2000. Rancangan Percobaan Praktis Bidang Pertanian. Penerbit Kanisius. Yogyakarta.

Thalib, A., B. Haryanto, H. Hanid, D. Suherman \& Mulyani. 2001. Pengaruh kombinasi defaunatior dan probiotik terhadap ekosistem rumen dan performan ternak domba. J. Ilmu Ternak dan Veteriner, 6 (2):83-88.

Williamson. G. dan W.J.A., Payne, 1993. Pengantar Peternakan di Daerah Tropis, Universitas Gadjah Mada, Yogyakarta. 